\title{
LA REDENCIÓN DEMOCRÁTICA: MÉXICO 1821-1861
}

\author{
José Antonio Aguilar Rivera* \\ Centro de Investigación y Docencia Económicas
}

\begin{abstract}
To es posible trazar el itinerario de la democracia en Mé1 xico en el siglo xIx sin atender los derroteros de esa voz en el resto del mundo occidental. Esa tarea es aún fragmentaria. Tienen razón Joanna Innes y Mark Philp cuando señalan que a mediados del siglo xviII el sustantivo "democracia" y el adjetivo "democrático" se referían al mundo antiguo: Grecia y la Roma republicana. ${ }^{1}$ Es notable que cuando se inventó el gobierno representativo, específica y deliberadamente como una alternativa moderna a la democracia, ésta tuviera muy pocos referentes institucionales concretos. Más que un orden institucional, la
\end{abstract}

Fecha de recepción: 5 de septiembre de 2018

Fecha de aceptación: 12 de diciembre de 2018

* El autor desea expresar su agradecimiento a Carlos Arroyo Batista por su apoyo en la investigación y preparación de este trabajo. Eduardo Posada Carbó leyó el ensayo e hizo valiosos comentarios críticos. Una versión preliminar de este trabajo fue presentada en el panel "The Language of Democracy in Latin America During the Age of Revolutions, c. 1750-1850s", Latin American Studies Association, Barcelona, 23-26 de mayo de 2018. Agradezco, de igual forma, las críticas de tres dictaminadores anónimos.

1 InNes y PhILP, Re-imagining Democracy, p. 1. 
democracia hacía referencia a un conjunto de fenómenos políticos: multitudes, agitación, demagogos en busca de apoyo popular, una política de arrebatos y la coacción sobre quienes se oponían a la voluntad del pueblo. En una palabra: "tumultos e inestabilidad". ${ }^{2}$

En el siglo xviri la democracia fue desprestigiada críticamente por la revolución francesa y su política del Terror. Por ello, entre 1820 y finales de la década de 1840 el término tuvo que ser repensado y vuelto a imaginar. Aunque durante este periodo gozó de muy poco favor, la reconceptualización que experimentó fue clave para su regreso, como un ave fénix, en 1848. La revolución de ese año volvió a poner a la democracia en las primeras páginas del mapa conceptual del mundo occidental.

El gobierno representativo no fue una "evolución" de la democracia clásica. Parte del problema a principios del siglo XIX era que el bagaje institucional de los nuevos sistemas políticos no pertenecía a la democracia, sino al gobierno representativo. Esta forma de gobierno había tomado algunos elementos democráticos y los había combinado con otros aristocráticos para formar un ente híbrido, una especie de Jano bifronte, como señala Bernard Manin. ${ }^{3} \mathrm{Ni}$ siquiera las elecciones tenían un incuestionable linaje democrático: eran más bien aristocráticas. ${ }^{4}$ Cómo logró la democracia naturalizarse en el seno del gobierno representativo es una historia compleja y con variaciones nacionales importantes. En algunos casos éste fue un proceso precoz. Por ejemplo, en Estados Unidos el término “democrático" dejó muy pronto de ser un epíteto. Como señala Cotlar, la democracia, como una palabra con connotación positiva, se naturalizó

\footnotetext{
2 InNes y PhILP, Re-imagining Democracy, p. 1.

${ }^{3}$ Manin, Los principios del gobierno.

${ }^{4}$ Aristóteles, La Política, libro IV, cap. 9, 1294b 7-9. “Lo que quiero decir es que se considera como democrático que las magistraturas se asignen por sorteo, como oligárquico que sean electivas, como democrático que no dependan de cualificaciones de propiedad y como oligárquico que dependan de ellas".
} 
entre 1790 y $1794 . .^{5}$ Temprano hubo un partido “demócrata” en Estados Unidos y para 1830 ya se publicaban numerosos diarios cuyos títulos incluían la palabra demócrata. Así, democracia se convirtió en sinónimo de soberanía popular. ${ }^{6}$ Sin embargo, en la práctica la "democracia” estadounidense era clásica, es decir, incluía esclavos. Por ello el concepto era restringido. ${ }^{7}$

En América Latina “democracia” no fue una voz hegemónica entre 1770 y $1870 .{ }^{8}$ En el siglo XviII tuvo las mismas connotaciones clásicas que en Europa y Estados Unidos. El sufragio universal, sin embargo, se naturalizó primero en México y otros países que en Francia. ${ }^{9}$ Ahí, igualmente, era un término generalmente negativo. En cierta forma, la democracia fue una especie de polizón que se introdujo en el navío del gobierno representativo mediante la idea, y práctica, de la representación. Como señala Jordana Dym para Centroamérica, “el término democracia empezó a cobrar connotaciones positivas como la equivalencia en la práctica con la representación electoral y a veces [como] sinónimo de república”. ${ }^{10}$ Sin embargo, no hay un solo camino conceptual para toda la región. Los matices abundan. Por ejemplo, en Nueva Granada ocurrió que la expresión “gobierno representativo" se extendió rápidamente, pero al mismo tiempo la voz democracia tuvo una connotación menos crítica que en otros lugares. ${ }^{11}$ Ahí es notable la escasez de voces "de repudio o desdén por la democracia".

5 Cotlar, “Languages of Democracy”, p. 21.

6 Sмiтн, “The 'Fortunate Banner'”, p. 28.

7 Al respecto véase Wilentz, The Rise of American Democracy, p. 558.

8 Caetano, “Itinerarios conceptuales”, p. 15.

9 Sobre la compleja historia del sufragio universal en Francia véase RosanVALLON, La consagración.

10 Dym, “Centroamérica”, p. 89.

11 Numerosos hombres públicos alegaron que "la democracia contenía también diversos ideales, los cuales prevalecieron sobre los temores". VANEGAS, “Colombia/Nueva Granada”, p. 123. 
Elisa Cárdenas ha trazado un mapa general de la travesía de la democracia en México en el siglo XIX. ${ }^{12}$ Ese viaje en sus inicios es similar al de otros países. En México "democracia” "no es de uso común en el vocabulario político mexicano sino hasta pasado el año de $1855 " .{ }^{13}$ Durante mucho tiempo el término permanece en un "segundo plano discursivo". Connotaba, como en muchos otros lugares, un imaginario vinculado a la revolución francesa con resonancias jacobinas. ${ }^{14}$ Los primeros proponentes del imperio en México contrapusieron la monarquía moderada a la desordenada "democracia”. ${ }^{15}$ Ciertamente, el consenso negativo sobre la democracia no era absoluto y es posible hallar casos aislados de referencias positivas. ${ }^{16}$ Por ejemplo, algunos autores intentaron separar a la democracia de la demagogia. ${ }^{17}$ En el curso de los debates del Acta Constitutiva y el Congreso de 1823-1824 los términos “democracia” y “democrático” fueron

12 Cárdenas Ayala, “México/Nueva España”, pp. 149-161; Cárdenas AyaLA, "La escurridiza”, pp. 73-91.

${ }^{13}$ Cárdenas Ayala, "La escurridiza”, p. 75.

14 Cárdenas Ayala, "La escurridiza”, p. 75.

15 Juan de Dios Piñera, Sermón panegírico encarístico que en honra de nuestro libertador el Sor. D. Agustín Primero emperador angusto del gran imperio del Anábuac en su exaltación al trono y día de su nacimiento dijo [...], Guadalajara, Imprenta Imperial de D. Mariano Rodríguez, 1822, citado por CÁrdenas Ayala, "La escurridiza", p. 79.

16 Es el caso del manifiesto del Congreso del Anáhuac del 15 de junio de 1814, en el cual se defiende la "forma democrática de Gobierno". "Manifiesto del Congreso a la Nación del 15 de junio de 1814", en Juan Eusebio Hernández Dávalos, Colección de documentos para la historia de la Guerra de Independencia de México de 1808 a 1821, México, INeHrm, 1985, p. 157, citado por Cárdenas Ayala, "La escurridiza”, pp. 77-78.

17 Véase, por ejemplo, el caso de Francisco Maldonado en torno de "la mejor de las democracias", referido por Cárdenas. Francisco Maldonado, Contrato de Asociación para la República de los Estados Unidos del Anábuac por un ciudadano del estado de Xalisco, Guadalajara, Poderes de Jalisco, 1973 [1823], p. 9, citado por Cárdenas Ayala, "La escurridiza”, p. 80. 
mencionados en pocas ocasiones. ${ }^{18}$ Lo cierto es que fuera de los debates legislativos la palabra aparecía en ocasiones relacionada con temas como la soberanía, la opinión pública, etc. En la prensa se menciona la democracia como una alternativa al absolutismo. Sin embargo, en las discusiones parlamentarias su empleo fue más restringido. La democracia no aparece en la primera constitución del país, en 1824. Sin embargo, todo esto comenzó a cambiar en la década de 1840 . Y, como señala Cárdenas, a partir de la década de 1850 la voz democracia se instaló plenamente en el discurso del país. Para entonces, "se ha producido un giro radical para connotarle positivamente: a los conceptos que la circundan y la nutren se han agregado decididamente la República, el liberalismo y la civilización". ${ }^{19} \mathrm{La}$ palabra democracia apareció muchas veces en los debates del Congreso Constituyente de 1856-1857. Estaba ya plenamente naturalizada. ¿Cómo ocurrió esto?

\section{EL CALLEJÓN SIN SALIDA DE LA MODERACIÓN: 1840-1848}

Redimir a la democracia de sus connotaciones negativas históricas en la década de 1840 fue un trabajo arduo. Ese proceso tomó una forma rara vez vista en México: la constitución mixta. En el pensamiento clásico, desde Aristóteles y Polibio, la mezcla de formas de gobierno puras (monarquía, aristocracia y democracia) era una manera de mantener la estabilidad de la república al dar participación institucional a pobres y ricos, clases en eterno conflicto. El propósito de esta "mezcla” era que ninguna de ellas tuviera el poder absoluto en el estado. La idea de la

18 Para una muestra: en las sesiones del 28 de noviembre de 1823 y del 7 de diciembre de 1823 se mencionó la palabra “democracia” y en la del 13 de octubre de 1824 se mencionó en dos ocasiones el término “democrático”. CÁMARA DE Diputados, Crónicas del Acta, pp. 141-142, 240-241; CÁmara De Diputados, Crónicas: Constitución, pp. 114-115, 135, 844-845.

19 Cárdenas Ayala, "La escurridiza”, p. 76. 
soberanía, en especial la popular, era antitética a la constitución mixta. Por eso esta última no fue parte de la teoría política del gobierno representativo, con la notable excepción de Inglaterra y su constitución “templada”. En Estados Unidos sólo uno de los "padres fundadores", John Adams, propuso la constitución mixta, pero en general la opinión era que en Estados Unidos no había "nada que mezclar".20

La palabra democracia fue empleada en la lucha que desde los primeros años de la primera república federal sostuvieron las facciones centralista y federalista. Ambos bandos trataron de apropiarse del término para justificar y legitimar sus proyectos políticos. A partir de que se conoció el libro La democracia en América de Alexis de Tocqueville la palabra gozó de un prestigio significativo. En esos debates se recurrió a la "democracia" como un componente del sistema federal. También se exploró de manera polémica la relación entre ésta y el centralismo administrativo. En este periodo subsiste cierta desconfianza hacia la democracia, en parte por el saldo político de movilizaciones populares de la década de 1820, como la destrucción del mercado del Parián en 1828.

Probablemente el mayor redentor de la democracia en México en la década de 1840 fuera Mariano Otero. Es posible dar cuenta de tres intervenciones diferentes. La primera tiene que ver con la distinción analítica entre el principio de la soberanía popular y la democracia en el contexto del debate sobre el federalismo, la segunda se ocupa de las bases sociales de la democracia y la tercera aborda su dimensión propiamente institucional.

20 Adams, "A Defence of the Constitutions of the Government of the United States of America", p. 131; Bernard Manin, "Checks, balances and boundaries: the separation of powers in the constitutional debate of 1787", citado en FonTANA, "Introduction: the invention of the modern republic", en The Invention of the Modern Republic, pp. 60-62. 


\section{Soberanía y democracia}

En 1842 un congreso constituyente, compuesto de una mayoría de federalistas, fue electo a pesar de la oposición del general Santa Anna. El 10 de julio de 1842 la Asamblea Constituyente abrió sus sesiones. Se nombró una comisión redactora compuesta por siete miembros: cuatro de ellos favorecían el centralismo, mientras que los otros tres, entre ellos Otero, apoyaban un sistema republicano federal. ${ }^{21} \mathrm{El} 26$ de agosto de 1842 dos informes le fueron presentados al pleno del Congreso. El primero estaba firmado por cuatro miembros de la comisión y el segundo era un informe de la minoría. Mientras que los federalistas dominaban el Congreso, los centralistas tenían la mayoría en la comisión redactora. Cuando se presentó el proyecto de los centralistas al pleno fue derrotado y regresado a la comisión. Ésta entonces rescribió la propuesta y el 3 de noviembre de 1842 presentó un nuevo proyecto. Se intentó en este nuevo documento construir un puente entre federalistas y centralistas. Sin embargo, el 11 de diciembre de 1842, antes de que se discutiera este nuevo proyecto en el Congreso, ocurrió un pronunciamiento en el pueblo de Huejotzingo. En las siguientes semanas varias guarniciones alrededor del país se unieron al pronunciamiento. El 19 de diciembre Santa Anna cerró el Congreso y desbandó a los diputados. La constitución de 1842 abortó porque no se conformó según los deseos del caudillo.

El dictamen de la mayoría centralista de la comisión fue criticado por Otero en diversos aspectos. ${ }^{22}$ En su crítica expuso

${ }^{21}$ Los cuatro centralistas fueron Antonio Díaz Guzmán, Joaquín Ladrón de Guevara, José Fernando Ramírez y Pedro Ramírez. La minoría federalista estaba compuesta por Mariano Otero, Octaviano Muñoz Ledo y Juan José Espinosa de los Monteros.

${ }_{22}$ Mariano Otero, "Examen analítico. El sistema constitucional”, El Siglo Diez y Nueve (3 oct. 1842), pp. 2-3. 
la confusión entre "soberanía popular" y "democracia”. Los centralistas habían consignado:

[...] la comisión reconoce que la soberanía reside esencialmente en el pueblo, y de este principio es consecuencia necesaria que la democracia sea la basa elemental de las instituciones que deben regirlo: decimos basa elemental y tomamos esta frase en todo el rigor de su sentido, para manifestar que la democracia será el primer elemento de nuestras instituciones, que ella dominará en su organización; pero que no será la forma de nuestro gobierno. ${ }^{23}$

Otero leyó correctamente a Tocqueville y criticó esta interpretación, aduciendo que la comisión confundía el origen de la legitimidad con la forma de gobierno. Citó pasajes de Destutt de Tracy y de Rousseau para demostrar que el pueblo soberano podía adoptar como forma de gobierno la democracia, la aristocracia o la monarquía. Adujo:

Cuando se proclama "la soberanía del pueblo no se proclama, como dice el Proyecto, el imperio de la democracia ni se le constituye en primer principio ni a ella ni a alguna otra forma de gobierno, sino que reconociéndose únicamente, como dice Destutt de Tracy, que la Nación tiene derecho de modificar y variar su constitución y que ningún poder tiene el de oponerse a la voluntad general manifestada en las formas convenidas, se reconoce por el contrario que la Nación tiene el derecho de adoptar cualquier forma de gobierno. ${ }^{24}$

La facción centralista respondió a este argumento por medio del ministro de (Guerra, José María Tornel, en un discurso pronunciado el 12 de octubre de 1842) y publicado en la prensa

${ }^{23}$ El párrafo del dictamen está citado por Otero en su texto publicado el 3 de octubre de 1842 en El siglo Diez y Nueve. Mariano Otero, "Examen analítico", p. 1.

${ }^{24}$ Mariano Otero, “Examen analítico”, p. 1. 
hasta el 30 de noviembre de 1842 apenas 11 días antes del pronunciamiento en Huejotzingo, y cuando) en el congreso se debatía el nuevo dictamen de la comisión de redacción presentado el 3 de noviembre. Tornel empleó a Alexis de Tocqueville para defender el dictamen de la mayoría. En su discurso hizo una larga cita del capítulo 3 de la segunda parte de La democracia en América: ${ }^{25}$

¿Cómo podría desentenderse la comisión de fijar como base a la democracia, tratándose de dar constitución para un pueblo, y especialmente para un pueblo americano? Obrando la comisión con el intento de conservar un centro de acción para el movimiento social, la democracia era para ella una necesidad, porque el centralismo es, aunque parezca una paradoja, su primera tendencia. Así lo piensa el ilustre académico Alexis de Tocqueville, el mismo que es justamente considerado como el apóstol de las democracias y el que ha logrado hacer popular la constitución de Estados Unidos de América. "El odio", dice, "que los hombres profesan a los privilegios, se aumenta a proporción que ellos son más raros y menores, de modo que puede asegurarse, que las pasiones democráticas, se inflaman más, cuando encuentran menos aliento. Yo he dado ya la razón de este fenómeno. Cuando todas las condiciones son desiguales, no hay desigualdad tan grande que pueda herir los intereses, al paso que la más pequeña desemejanza parece que choca en el seno de la uniformidad general; su vista que llega a ser más insoportable, a medida que la uniformidad es más completa. Es, pues, natural que el amor de la igualdad crezca sin cesar con la igualdad misma; se desarrolla cuando se satisface. Este odio inmortal que incesantemente se desenvuelve en los pueblos democráticos contra los privilegios especiales, favorece singularmente la concentración gradual de

25 "Los sentimientos de los pueblos democráticos están de acuerdo con sus ideas para inclinarlos a concentrar el poder". TocQueville, La democracia en América, pp. 617-618. Más sobre este tema en Aguilar Rivera, "Omisiones del corazón”, en Ausentes del universo, pp. 29-67. 
todos los derechos políticos en las manos del único representante del estado. Hallándose el soberano elevado necesariamente y sin réplica sobre todos los ciudadanos, no excita la envidia de ninguno de ellos, y cada uno cree despojar a sus iguales de la prerrogativa que le concede. [...] Todo poder central que sigue sus instintos naturales, ama la igualdad y la favorece [...] Esta comunidad de sentimientos, que entre las naciones democráticas une de continuo en un mismo pensamiento a todo individuo y al soberano, establece entre ellos una secreta y permanente simpatía". ${ }^{26}$

Cabe decir que las conclusiones que Tocqueville sacaba de este análisis no eran nada halagüeñas. ${ }^{27}$ Sin embargo, Tornel había logrado demostrar que la democracia estaba vinculada a la centralización de una manera indirecta, pero férrea. ${ }^{28}$ Satisfecho, afirmó:

He aquí cómo un escritor célebre, que es acusado hasta de exageración en sus principios, conviene en que la centralización del poder es no solamente una tendencia sino también una necesidad en los pueblos democráticos, y como él raciocina y prueba, justifica anticipadamente a la comisión que estableció la democracia, como primera base de su proyecto. ${ }^{29}$

${ }^{26}$ José María Tornel, "Discurso pronunciado por el Xcmo. Sr. General, ministro de guerra y marina D. José María Tornel, en la sesión del 12 de octubre de 1842 del congreso constituyente, en apoyo del dictamen de la mayoría de la comisión de constitución del mismo", El Siglo Diez y Nueve (30 nov. 1842), p. 1. 27 "Creo que en los siglos democráticos que ahora empiezan, la independencia individual y las libertades locales serán producto del arte. La centralización será el gobierno natural”. TocQueville, La democracia en América, p. 618.

${ }^{28}$ La lectura es equívoca, pues Otero se había referido a la democracia como forma de gobierno, mientras que Tocqueville se refiere a ella como igualdad de condiciones, no como un régimen político. Como muchos han hecho notar, a lo largo de La democracia en América el significado de la palabra "democracia" se alterna entre uno y otro.

${ }^{29}$ José María Tornel, “Discurso pronunciado por el Xcmo. Sr. General, ministro de guerra y marina”, p. 1. 
Y proseguía:

Admitida la democracia como fundamento de la constitución mexicana, no puede caber duda de que la forma de gobierno debe ser popular y también representativa porque desde que las repúblicas no han estado reducidas a un pequeño recinto, como en Grecia, ni sus derechos a una sola ciudad, como en Roma, no es posible que ellos se ejerzan si no es por medio del sistema representativo, que presta facilidades, excluye el desorden y hace que se encomiende a los ciudadanos más provectos e ilustrados la dirección de la cosa pública. Así, que la discusión justamente se versa, suponiendo que nuestro gobierno ha de ser y no puede ser más que republicano, sobre el modo de realizarlo; es decir, que la cuestión propia, y que trataremos con lealtad, es la de si es conveniente en el estado verdadero y no ideal de la república, el sistema federal desarrollado en toda su extensión, o más bien el que propone la mayoría de la comisión con un pulso y tino que tanto merecen un desapasionado elogio. ${ }^{30}$

Tornel no mencionaba que Tocqueville encontraba aspectos muy preocupantes en la centralización. No sólo eso, sino que al referirse al "centralismo", Tocqueville tenía en mente un fenómeno mucho más amplio -y peligroso- que la simple organización en departamentos de una república. Lo notable de este debate es que tanto Tornel como Otero se referían a la democracia de una manera nueva. Sus alegatos encontrados no pertenecen al discurso prevaleciente hasta la tercera década del siglo xix. La democracia ahora era entendida como una realidad sociológica, a la manera de Tocqueville.

${ }^{30}$ José María Tornel, “Discurso pronunciado por el Xcmo. Sr. General, ministro de guerra y marina”, p. 1. 


\section{Las bases sociales de la democracia}

Ese mismo año Otero publicó su Ensayo sobre el verdadero estado de la cuestión social y política. ${ }^{31}$ En ese texto Otero reflexionó sobre la dimensión social de la democracia. Señalaba:

Son sin duda muchos y numerosos los elementos que constituyen las sociedades, pero si entre ellos se buscara un principio generador, un hecho que modifique y comprenda todos los otros y del que salgan como de un origen común todos los fenómenos sociales que parecen aislados, éste no puede ser otro que la organización de la propiedad. Ella ha constituido el despotismo en los pueblos del Asia [...] ella constituyó las aristocracias de la antigüedad, y ella sola ha fundado la democracia. ${ }^{32}$

La democracia estaba, de esta manera, críticamente vinculada a un origen social. En efecto, en el norte del continente

[...] la población comenzó por una verdadera colonización: numerosas reuniones de sectarios de la Reforma fueron a buscar un asilo contra el infortunio que los perseguía, y sin ningún título que los hiciera desiguales los unos a los otros, se vieron forzados todos a dedicarse a la agricultura, aplicando su trabajo personal a las fatigas del cultivo; y de allí vino esta población profundamente democrática, que se ha presentado después al mundo como la realización más asombrosa de la igualdad social. ${ }^{33}$

En cambio, en la América española los conquistadores, ávidos de oro, "quisieron hacer los grandes señores y reunir grandes riquezas, para lo que se repartieron el territorio en grandes

31 Otero, Ensayo sobre el verdadero estado.

32 Otero, Ensayo sobre el verdadero estado, p. 35.

33 Otero, Ensayo sobre el verdadero estado, pp. 47-48. 
porciones, y les fue preciso buscar quienes las trabajasen para ellos". ${ }^{34}$ Primero explotaron a los indígenas y cuando la población de los nativos decayó importaron esclavos de África, los cuales, "reunidos con los anteriores [pobladores] y mezclados con los españoles, han producido esa población abyecta y miserable que forma los cuatro quintos de la total de la república, y que representa aquella parte que en todas las sociedades humanas está destinada a la miseria". ${ }^{35}$ Las bases sociales de la democracia, entonces, no existían en México.

Este reconocimiento, empero, era problemático, porque parecía darles la razón a los críticos del experimento constitucional liberal. En particular a quienes, como Tornel, pensaban que en México no existían las condiciones para establecer formas de gobierno como el federalismo. Ante esta dificultad, Otero procede, en primer lugar, a definir a la democracia como un principio mayoritario de gobierno, a la manera de Montesquieu. ${ }^{36}$ En efecto: "en las sociedades constituidas hay un principio dominante que decide las cuestiones políticas o administrativas que siempre se suscitan: la voluntad de un señor en el despotismo: los intereses de los nobles en la aristocracia, y el voto de la mayoría en los estados democráticos...". ${ }^{37}$ Este principio mayoritario operaba independientemente de las bases sociales de la democracia.

La segunda operación consistió en desvincular teóricamente a la democracia (con sus prerrequisitos culturales) del federalismo. Para ello recurrió de nueva cuenta al ejemplo de Estados Unidos. ¿Qué era lo que había inventado ese país? Otero respondía:

\footnotetext{
${ }^{34}$ OTERo, Ensayo sobre el verdadero estado, pp. 47-48.

35 Otero, Ensayo sobre el verdadero estado, p. 48.

${ }^{36}$ Para Montesquieu un principio es aquello que hace actuar a un gobierno. Montesquieu, El espiritu de las leyes, libro III, cap. 1.

37 Otero, Ensayo sobre el verdadero estado, p. 73.
} 
[...] que sea lícito decir que en sus instituciones asombrosas, que en esas instituciones admiradas de todos los pueblos, no es el principio federal lo que ha parecido nuevo ni sorprendente, sino la realización de un gobierno interior, en el que bajo las formas republicanas, el sistema representativo ha llegado a tal punto de perfección, que se confunde ya con la democracia, evitando sus inconvenientes. ${ }^{38}$

Las formas políticas que requerían de costumbres y hábitos tocquevillianos ("un pueblo libre y sabio") eran, según Otero, la república y “el sistema popular”, no la federación. Ésta, en cambio, era

[...] un lazo común para la democracia, como para la aristocracia: de esa manera ha existido en la historia, y por eso la hemos visto conservarse en el desorden de la anarquía, como en medio de los furores de la oligarquía, sobreviviendo a uno y a otros, porque ella [...] no reconoce otro principio que [...] el gobierno republicano no puede plantearse en una vasta extensión de territorio, sino bajo las formas federales. ${ }^{39}$

El propósito retórico de Otero era hacer ver que los adversarios centralistas de la federación en realidad eran críticos del "sistema popular", algo que éstos negaban. Sin embargo, Otero defendía el federalismo a costa de poner en duda la viabilidad misma de la república.

\section{La democracia en su lugar}

Para 1847, cuando se restauró la constitución federal de 1824, la democracia había ya avanzado un largo trecho en el camino de

38 Otero, Ensayo sobre el verdadero estado, p. 119.

39 Otero, Ensayo sobre el verdadero estado, p. 119. 
la redención. Sería readmitida en el seno del gobierno representativo, pero en su debido sitio. Había dejado de ser un término de connotaciones exclusivamente negativas para convertirse en un fenómeno sociológico y en un horizonte deseable... en ciertas condiciones. ¿Cuáles eran esas condiciones?

El lugar de la democracia puede constatarse en el voto particular de Otero en el Congreso Constituyente de 1847.40 Ahí declaró: "la conservación del sistema federal, el establecimiento de los principios liberales y filosóficos que corresponden a nuestro siglo, el desarrollo rápido y seguro de la democracia, están y han estado siempre unánimemente admitidos en el Congreso". ${ }^{41}$ Las cláusulas de la readmisión de la democracia pasaban por una apología. La discusión tranquila reemplazaría a las pasiones demagógicas. Así Otero aducía:

[...] si toda la teoría de la democracia representativa se redujera a llamar al pueblo un día para que eligiera sus mandatarios y les abandonara después la dirección de los negocios, sería cierto, como algunos escritores pretenden, que el sistema representativo no había podido reemplazar a las antiguas formas, mientras que dejando al pueblo la constante participación y dirección de los negocios públicos por los medios pacíficos de la discusión se coloca a los representantes bajo el influjo de sus propios comitentes, a los negocios bajo el poder de la opinión pública; y de esta manera la acción tranquila y razonada del pueblo sustituye con mil ventajas al embate de las pasiones de la multitud, engañada en el foro por las intrigas de la ambición o por la fascinadora elocuencia de los tribunos. Aun bajo los gobiernos monárquicos, donde el elemento

40 Mariano Otero, "Voto particular presentado al Congreso constituyente en la sesión del 5 de abril de 1847”, en Aguilar Rivera, La espada y la pluma, pp. 247-276.

${ }_{41}$ Mariano Otero, "Voto particular", en Aguilar Rivera, La espada y la pluma, p. 247. Mis cursivas. 
democrático está sujeto a mil trabas y subordinado a otros adversos poderes, se admira cómo la mayoría, ayudada de estos resortes poderosos, llega a tomar la dirección de los negocios y avanza todos los días en grandeza y en poder. Estos medios son de esencia en el sistema representativo. ${ }^{42}$

La democracia no desplazaría al sistema representativo: simplemente lo complementaría. El sitio de la democracia era un lugar institucional equilibrado por otros elementos aristocráticos. Esto puede verse en la defensa de Otero del bicameralismo:

[...] se presenta luego el legislativo ejercido por un Congreso compuesto de dos cámaras. Popular y numerosa la una, representa la población y expresa el principio democrático en toda su energía. Más reducida y más lenta la otra, tiene un doble carácter muy difícil, pues representa a la vez a los cuerpos políticos considerados como iguales y viene a llenar la urgente necesidad que tiene toda organización social de un cuerpo, depósito de sabiduría y de prudencia, que modere el ímpetu de la democracia irreflexiva, y en el incesante cambio personal de las instituciones populares, conserve la ciencia de gobierno, el recuerdo de las tradiciones, el tesoro, por decirlo así, de una política nacional. ${ }^{43}$

Esta pulsión conservadora era consistente con el gobierno representativo.

Otero reintegraba el elemento democrático, que era uno de los componentes originales del gobierno representativo, pero equilibrándolo con otros elementos que neutralizarían los riesgos inherentes a la democracia. Del lado democrático

${ }^{42}$ Mariano Otero, "Voto particular", en Aguilar Rivera, La espada y la pluma, p. 254. Mis cursivas.

43 Mariano Otero, "Voto particular", en Aguilar Rivera, La espada y la pluma, p. 256. Mis cursivas. 
proponía, a diferencia de la constitución de 1824, una cámara de diputados extensa. Otero creía que solo un crecido número de individuos podía ser expresión del "elemento democrático". ${ }^{44}$ En cuanto al sufragio censitario, estaba en contra de las restricciones al voto. ${ }^{45}$ Sin embargo, Otero también creía firmemente en la necesidad de un senado aristocrático, eventualmente electo por los ciudadanos. La cámara alta se compondría de hombres experimentados y se consideraría "como el honroso término de la carrera civil”. El senado constituiría una aristocracia electiva. $\mathrm{Si}$, afirmaba, para

[...] el cuerpo más importante, el más influyente, duradero y respetable del Estado, se recurre para el acierto de la elección a ese admirable medio que contienen las instituciones democráticas [...] solo una reputación distinguida podrá obtener los sufragios de la mayoría de los ciudadanos. Confiando, pues, en estos medios, tengo la ilusión de creer que sin desnaturalizar la democracia, sin exclusiones odiosas ni privilegios inmerecidos, habremos acertado con el principal punto de nuestra organización política. ${ }^{46}$

Mientras tanto, y hasta que "la elección directa de senadores entra en nuestras costumbres constitucionales", los estados y la cámara de diputados designarían a los miembros del senado, combinando así "la democracia y la federación".

\footnotetext{
${ }^{44}$ Mariano Otero, "Voto particular", en Aguilar Rivera, La espada y la pluma, p. 257.

${ }_{45} \mathrm{El}$ argumento de Otero es muy curioso y amerita una discusión aparte. Aunque reconocía la existencia del "principio de distinción" -la idea propia del gobierno representativo de que los representantes debían ser socialmente superiores a aquellos que los elegían- no creía que el tipo de restricciones acostumbradas para asegurar la superioridad de los candidatos lograra su cometido. Manin, Los principios del gobierno representativo, pp. 119-120.

${ }^{46}$ Manin, Los principios del gobierno representativo, p. 260.
} 
Elogio de la constitución mixta

Menos prominente, pero de mayor importancia teórica, fue la intervención de Nicolás Pizarro (1830-1895), un político y novelista liberal. ${ }^{47}$ Pizarro da cuenta del último intento de moderar la readmisión plena de la democracia en el seno del gobierno representativo. ${ }^{48}$ Lo notable de esta alternativa fue que abogaba abiertamente por la constitución mixta del republicanismo clásico. La propuesta está plasmada en el panfleto La Libertad en el orden publicado en $1855 .{ }^{49} \mathrm{El}$ alegato es inevitablemente extemporáneo, pues apareció siete años después de la revolución de 1848, que conmovió a Francia y al mundo y que redimió al discurso democrático. Pizarro, de manera inusual, empezaba formulando la idea de que sólo existían dos formas de gobierno: "democrático representativo y monárquico absoluto" ${ }^{50}$ Ya no se trata del "gobierno representativo", como era costumbre, sino de un ente nuevo, cuyo sustantivo era "democrático". La dicotomía servía a Pizarro para exponer su teoría de la anaciclosis, es decir, la idea clásica, recuperada por Maquiavelo, de una sucesión cíclica de regímenes políticos. ${ }^{51}$ La solución canónica a la anaciclosis era el gobierno mixto. Afirmaba Pizarro:

47 Sobre el muy peculiar Pizarro, véase Illades y Sandoval, "Nicolás Pizarro", pp. 26-40.

${ }^{48}$ Sobre la idea de moderación en el pensamiento continental, véase CRAIUTU, $A$ Virtue.

${ }^{49}$ Pizarro, La libertad en el orden.

50 Pizarro, La libertad en el orden, p. 14.

${ }^{51}$ Maquiavelo pensaba que la monarquía llevaba inexorablemente a su forma corrompida, la tiranía, y que ésta provocaba una reacción de los ricos, que instituían una aristocracia. A su vez, el abuso de esta forma "pura" degeneraba en oligarquía, lo que acababa provocando una insurrección popular que entronizaba una democracia. Finalmente, los abusos de la gente llevaban a una demagogia a la cual ponía fin un hombre virtuoso, instituyendo una monarquía. Así, en un ciclo sin fin. Esto es lo que se conoce como anaciclosis. 
[...] todos los gobiernos por sus principios tienen la forma mixta, sin la cual no serían durables; todos en su acción propenden a una forma pura, esto es, a su destrucción. La mejor constitución es aquella en que se combina con más inteligencia el elemento democrático y el aristocrático, para que den por resultado una libertad racional al común del pueblo, una justa distinción al talento y a la propiedad, y mayor fuerza en el gobierno, todo lo que contribuye muy poderosamente a la más larga vida de una nación. ${ }^{52}$

Para elaborar su teoría, Pizarro daba cuenta del papel que desempeñaban las “mayorías democráticas” y las “minorías aristocráticas”. ${ }^{53} \mathrm{El}$ autor identificaba a los derechos universales de los individuos como el "principio democrático". Los derechos de "seguridad individual, el de propiedad, el de libertad de trabajo [...] el de libertad de pensamiento y por consiguiente de conciencia: todos estos derechos suponen en el gobierno la obligación de protegerlos aunque se trate del individuo más insignificante”. En cambio, los derechos políticos, "que no se conceden a todos de una misma manera, porque no podrían ejercerse sin inconveniente por la multitud", constituían el principio aristocrático. ${ }^{54}$ Derechos políticos eran: “el de armarse para pertenecer a la guardia civil, el de reunirse para tratar negocios políticos o particulares en lugar público y [...] el de escribir y publicar por medio de la prensa las ideas propias o ajenas". Nótese que esta peculiar clasificación niega la noción moderna de los derechos políticos como esencialmente democráticos.

Hecha esta distinción, Pizarro citaba largamente a Montesquieu en El espíritu de las leyes, cuando éste afirmaba que:

52 Maquiavelo, Discursos, I, 2.

53 Pizarro, La libertad en el orden, p. 25.

54 Pizarro, La libertad en el orden, p. 26. 
[...] en el Estado popular, el pueblo se divide en clases. Los grandes legisladores se han distinguido por la manera de hacer estas divisiones; de ellas dependen siempre la duración de la democracia y su prosperidad [...] la división de los que tienen derecho a votar en la república es una ley fundamental, y lo es igualmente el modo de dar el voto. ${ }^{55}$

Del análisis de Montesquieu, Pizarro destacaba que el romano Servio Tulio "puso el derecho al voto en manos de los ciudadanos principales”. Así, a diferencia de Otero, Pizarro concluía que "el primer derecho político, que es el de elegir los altos funcionarios, no puede concederse a las clases ignorantes [...] Lo mismo es aplicable a los extremadamente pobres y con mayor razón a los que por sus vicios o sus delitos están bajo el poder de las leyes criminales" ${ }^{56}$ Los otros derechos políticos también debían restringirse.

Pizarro no había abandonado las prevenciones clásicas sobre los peligros de la oclocracia. En efecto,

[...] cuando la constitución o la costumbre permiten a todos los que habitan un país el uso de los derechos naturales y políticos ejercidos sin distinción, se forma una democracia turbulenta, para la cual no valen los respetos de un senado, que siempre se ve en tales ocasiones luchando desventajosamente por conservar la unidad administrativa. ${ }^{57}$

El temor canónico al gobierno de los pobres se basaba en la amenaza de expropiación de las clases poseedoras. Así, creía Pizarro,

${ }_{55}$ Montesquieu, El espíritu de las leyes, cap. 2, libro II. Pizarro, La libertad en el orden, p. 26. Énfasis del autor.

56 Pizarro, La libertad en el orden, p. 27.

57 Pizarro, La libertad en el orden, p. 27. 
[...] encuentra entonces la multitud que las tierras están repartidas con una desigualdad monstruosa y promueve las leyes agrarias; exagerando la avaricia de los prestamistas exige la abolición de las deudas y trastorna los poderes del Estado creando magistrados populares que permanentemente se oponen al ejercicio de las facultades naturales de los demás.

Es cierto que estas democracias tenían el vigor de las repúblicas clásicas, sobre todo en lo que hace a su defensa; "si en tal situación se ofreciese un peligro exterior, aquella democracia se lanzaría contra sus enemigos abatiéndolos por su arrojo, por su entusiasmo y abnegación: son invencibles cuando encuentran la resistencia y la amenaza que las exalta”. Sin embargo, esas mismas democracias eran "incapaces de organizar de un modo estable su régimen interior y su propio poder, de que resulta que cuando les falta el peligro exterior se dividen formando sangrientas facciones" ${ }^{58}$

Pizarro, con el lente republicano, veía con mucha mayor claridad que Otero el pilar aristocrático del gobierno representativo. Los antiguos, razonaba Pizarro, que no conocieron los gobiernos representativos, o fundaron democracias "como las que acabamos de describir" o "se sujetaron al gobierno monárquico despótico”. El gobierno representativo era la solución a este dilema entre caos y servidumbre. El no ejercicio directo de varios derechos políticos "templa mucho la impetuosidad, tan natural a la multitud cuando se apasiona. El principio representativo introducido en la democracia evita que el pueblo con cien mil brazos todo lo trastorne". ${ }^{9}$ De igual manera, la ausencia del principio representativo agudizaba, pensaba Pizarro, la concentración del poder y la rigidez del absolutismo. No había un punto medio entre la demagogia y la esclavitud política. En

58 Pizarro, La libertad en el orden, p. 28.

59 Pizarro, La libertad en el orden, p. 28. 
cambio, “al traerse las cuestiones de la plaza pública a un congreso de representantes, se ha introducido en el gobierno del pueblo un elemento aristocrático que le da más consistencia y que asegura el orden". ${ }^{60}$

Curiosamente, Pizarro veía al gobierno representativo como una especie de nueva constitución mixta. El éxito de ese expediente estaba en la correcta mezcla de ambos principios. En efecto,

[...] si por no tener el conocimiento práctico de la fuerza relativa de estos elementos, en determinadas circunstancias, conforme a la índole, tradiciones y grado de instrucción común en el pueblo se ha hecho una mala combinación, la experiencia viene muy pronto a indicarlo, y si no se atiende el mal, o si por una fatalidad originada de la ceguera de los partidos [...] no se ha dejado en la constitución un medio fácil y pronto para aplicar el correctivo, viene luego el conflicto entre los poderes creados y no tarda la revolución en destruir la legalidad”. ${ }^{61}$

De esta manera, como lo hizo Adams en el caso de Estados Unidos, se reivindicaba la anacrónica constitución mixta:

[...] en el mundo físico y moral todo está combinado de manera que por el equilibrio de fuerzas contrarias resulta el orden y este artificio tan admirable no podía faltar en la política. De aquí es que el triunfo mismo de tal o cual principio lo debilita y hace que no tenga un momento después de la victoria la fuerza que desplegó al tiempo de la lucha.

Es preciso destacar que Pizarro no se refería a la división de poderes, al sistema de frenos y contrapesos del constitucionalismo

60 Pizarro, La libertad en el orden, p. 28.

61 Pizarro, La libertad en el orden, p. 28. 
moderno. El referente era Roma, "que nunca dejó que se borrasen las distinciones de senadores y caballeros". ${ }^{62}$ El gobierno mixto era, pensaba Pizarro, producto de la prudencia del gobernante:

A nuestro modo de ver, la ciencia del hombre de Estado consiste en esta combinación de elementos tan varios y a veces encontrados, que en toda nación es forzoso que influyan, a fin de que resulte el equilibrio, no entre los funcionarios que se establecen, sino de las fuerzas vitales de la misma nación, de manera que a la vez que cada una de ellas siga su natural desarrollo, las otras se dirijan a los fines sociales que se tratan de alcanzar. ${ }^{63}$

Pizarro creía que, al igual que la revolución francesa, la democracia no debía ser detenida, sino más bien dirigida y después moderada. El principio democrático, abandonado a sí mismo, se corrompía y daba entrada a la anarquía y el despotismo. Así, había que volver la vista a la historia, a Roma:

[...] lo más importante no era ciertamente el mecanismo y aparato de su administración, en la que había sin duda mucho que admirar, lo principal era el espíritu que la vivificaba. Censores, cónsules, senado, dictadores, Tribunos, etc., todo puede ensayarse en una república; pero nada habrá adelantado, si en ella impera solamente la democracia pura, o la aristocracia sin el pueblo. ${ }^{64}$

62 Pizarro, La libertad en el orden, p. 31. "Roma [...] fue grande y gloriosa mientras no salió del círculo de una democracia contenida por la virtud e influencias de la aristocracia, y viceversa, mientras fue una aristocracia a la que moralizaba el temor del pueblo. Leyes, riqueza, poder, orden y libertad, todo vino de aquí, y todo faltó cuando se destruyó la combinación de su gobierno.”

63 Pizarro, La libertad en el orden, p. 29.

${ }^{64}$ Pizarro, La libertad en el orden, p. 32. 
Pizarro aterrizaba esta teoría política republicana en la historia de México de forma notable. Anticipaba por un año el argumento de Alexis de Tocqueville sobre el antiguo régimen. ${ }^{65} \mathrm{En} E \mathrm{l}$ Antiguo Régimen (1856) Tocqueville argumentó que el camino a la revolución había comenzado mucho antes de 1789. El absolutismo preparó la revolución al destruir los cuerpos intermedios de la sociedad estamental. La revolución no crearía, sino que culminaría, este proceso de igualación de condiciones. Pizarro leía de manera similar la experiencia colonial mexicana. "El gobierno de los virreyes", aducía, "fue de tal manera excepcional, que no creemos haya otro ejemplo semejante de un despotismo templado por las leyes, por los cuerpos del Estado y por el rey a cuyo nombre se ejercía, y que preparó, sin que se conociese, el poder de la democracia". ${ }^{66}$ El absolutismo no destruyó, como en Francia, los poderes intermedios: éstos simplemente no existieron en América. En efecto,

[...] en Nueva España más bien había familias que clases privilegiadas, cuyo influjo era pasajero: los mismos virreyes [...] nada podían intentar que tuviese el aspecto verdaderamente aristocrático, puesto que el espíritu de la época no llevaba las distinciones más allá que lo que daban de sí la dominación y la dependencia, la calidad de español y la de americano. El día en que la dominación fuese vencida, nada quedaba respetable, si se exceptúa al clero. ${ }^{67}$

La ausencia de cuerpos moderadores hacía que el gobierno "popular representativo" resultara vital. Sin embargo, más indispensable, pensaba Pizarro, "era la ciencia política que en general faltaba”. La falta de perspectiva teórica hizo que no se

65 Tocqueville, El Antiguo Régimen.

${ }^{66}$ Pizarro, La libertad en el orden, p. 35. Cursivas mías.

${ }^{67}$ Pizarro, La libertad en el orden, p. 35. Cursivas mías. 
tomara la medida correcta de la situación histórica en la que se hallaba el país:

[...] todo lo que fuese ensanchar entonces las aspiraciones de la democracia era perderla, por no haber establecido contrapeso alguno que la contuviese. La ocasión, no obstante, era muy oportuna para establecer la aristocracia del mérito. Vivían algunos de los más famosos capitanes de la guerra de independencia, y la nación los hubiera visto con satisfacción y con orgullo, formando un senado vitalicio, y por lo mismo moderador, junto con los prelados que no contrariaron la independencia. ${ }^{68}$

En lugar de haber coronado a un solo prócer, “debió imponerse al pueblo el respeto de aquellos grandes hombres reunidos [...] a fin de que las pasiones encontrasen un invencible muro en el conjunto de aquella aristocracia del mérito y de la inteligencia". ${ }^{69}$ Pizarro comprendió que las instituciones del constitucionalismo liberal no creaban una aristocracia como la que anhelaba. No contendrían a una democracia que ansiaba la esperanza de "invadirlo todo, si era necesario a viva fuerza", como al final sucedió en 1828 durante el gobierno de Victoria. ${ }^{70}$ En 1854, en plena lucha contra la dictadura de Santa Anna, Pizarro hacía notar que esa tiranía había sido, paradójicamente, producto de aquella "insaciable democracia” que había “abierto sus propias entrañas” y sacrificado a sus más queridos hijos al comienzo de la república federal. La solución era instaurar un senado vitalicio y con él la venerable y sabia constitución mixta de los antiguos, en la cual ningún grupo o clase social sería soberano.

68 Pizarro, La libertad en el orden, p. 35.

69 Pizarro, La libertad en el orden, p. 35.

70 Pizarro, La libertad en el orden, p. 36. 
El impacto de la revolución de 1848 en el resto del mundo occidental difícilmente puede exagerarse. ${ }^{71}$ Un efecto de corto plazo fue volver a poner en circulación la palabra "democracia", esta vez con una connotación positiva. Ciertamente esta resurrección no fue bienvenida por todos. Como hace ver Clara Lida, después de una tibia recepción inicial los mexicanos -liberales y conservadores por igual- se volvieron críticos de lo que percibieron como excesos de la revolución de 1848 en Francia. ${ }^{72}$ Abundaron las condenas a la movilización popular y a la "anarquía” y el "comunismo". La historia sería muy distinta en Colombia y Chile, donde se produjo un notable fermento político y social. Es sorprendente que los conservadores mexicanos, naturalmente enemigos de la rehabilitación del término, dedicaran tan poco espacio a atacarla. Por ejemplo, Lucas Alamán en su Historia de México (1852) menciona sólo dos veces la palabra democracia. ${ }^{73}$ Luis G. Cuevas en Porvenir de México (1851) criticó en varios momentos las "exageradas máximas de la democracia" y censuró a los admiradores de la democracia estadounidense, pero el

${ }^{71}$ Para un análisis del impacto en América, véase Thompson (ed.), The European Revolutions.

${ }^{72}$ Clara E. Lida, "The Democratic", en Thompson, The European Revolutions, pp. 65-73.

${ }^{73}$ Alamán apunta sobre Iturbide al momento de la independencia: "Hay un partido liberal frenético, que aspira y sólo estaría contento con el libre goce de la licencia más desenfrenada; otro de liberales, que con ideas justas, aspiran a la moderación [...] hay otros ciegos partidarios de la democracia”. Y sobre el embajador Poinsett: "apenas llegó con el carácter de ministro plenipotenciario, formó el plan de hacer desaparecer el carácter hasta cierto punto aristocrático que el gobierno había conservado [...] para sustituir en su lugar, no una democracia, imposible en un país en el que el pueblo no toma parte en las cosas públicas, sino el aspirantismo desenfrenado de algunos individuos llenos de ambición y de menos respetables conexiones". Alamán, Historia de México, t. V, pp. 101, 623-624. 
término no aparece con mucha frecuencia en su libro tampoco. ${ }^{74}$ De igual forma, en el debate de 1849 en la prensa entre liberales y conservadores los términos de combate eran otros: soberanía, derechos naturales, etc. ${ }^{75} \mathrm{La}$ democracia no fue un blanco recurrente para los conservadores. ${ }^{76} \mathrm{Tal}$ vez, porque la muerte de algunos prominentes miembros de ese partido, como Alamán, sobrevino en los albores de la era democrática.

En general, las críticas conservadoras se enmarcaban en el conocido discurso del siglo xviII que retrataba a la democracia como un régimen anacrónico y tumultuario. Sin embargo, la revolución de 1848 mostró una nueva y preocupante cara del fenómeno. Los conservadores mexicanos no ignoraron del todo este rostro. Muestra de ello es que el editor conservador Rafael de Rafael tradujera y publicara el libro del doctrinario francés (y exministro de Luis Felipe) François Guizot, De la démocratie en France (1849). ${ }^{77}$ Guizot, víctima directa de la revolución que acabó con la Monarquía de Julio, hacía ahí la denuncia del fenómeno democrático. El panfleto fue publicado un año después de la revolución e inmediatamente traducido y editado en

\footnotetext{
74 "La república nada ha tenido que lamentar por esa proscripción de todos los principios y verdades morales que ha desolado a los pueblos apasionados por la democracia"; Cuevas, Porvenir de México, p. 181. La palabra "democracia" aparece en once ocasiones en ambos volúmenes de Cuevas, pp. 4, 6, 157, 181, 244, 254, 381, 405, 461, 516 y 523.

75 Véase Aguilar Rivera, Ausentes del universo, pp. 276-314.

${ }^{76}$ Hay dos menciones en el debate entre liberales y conservadores en la prensa de ese año. Antonio de Haro y Tamariz, por ejemplo, criticaba a Valentín Gómez Farías como un "representante de la democracia" que no gozaba de la confianza del pueblo. De igual forma: "nada arguyen contra las repúblicas la democracia anárquica de los atenienses, los errores de los hispanoamericanos y el drama sangriento de la convención nacional en 1793". De Haro y Tamariz, "Exposición que Antonio de Haro y Tamariz dirige a sus conciudadanos" (1848), en Palti (comp.), La política del disenso, pp. 97, 101. No se equivocaba, Gómez Farías sí fue un entusiasta de la revolución francesa de 1848. Clara E. Lida, "The Democratic", en Thompson, The European Revolutions, p. 67.

77 Guizot, De la démocratie.
} 
México. ${ }^{78}$ Esa crítica reconocía en primer lugar la novedad de la revuelta democrática. La celeridad con la que apareció el libro en castellano es muestra de que la democracia rediviva ciertamente les preocupaba a los conservadores. Más aún, es posible que hayamos subestimado el impacto de la revolución de 1848 en los conservadores. La muy inusual cepa de pensamiento conservador radical de esos años, original, universal y extrema, no puede explicarse sin esa revolución.

En su obra Guizot censuraba la "idolatría democrática". El caos, afirmaba, "se oculta hoy bajo una palabra: democracia. Ésta es la palabra soberana, universal; todos los pueblos la invocan y quieren apropiársela como un talismán" ${ }^{79} \mathrm{La}$ realidad semántica y política había dado un giro sorprendente: de mala palabra había pasado a mantra. "Tal es el imperio de la palabra democracia", argüía Guizot, "que ningún gobierno, ningún partido osa ni cree poder vivir sin inscribir esta palabra en su bandera, y que los que llevan esta bandera más alto y más lejos se creen los más fuertes" ${ }^{80}$ La democracia era la

[...] bandera de todas las esperanzas, de todas las ambiciones sociales de la humanidad, puras e impuras, nobles o bajas, sensatas o insensatas, posibles o quiméricas [...] para todos estos instintos paralelos y contrarios, para todos confusamente, los buenos como los malos, tiene perspectivas y promesas infinitas la palabra democracia $[. .$.$] he ahí el secreto de su fuerza.$

La democracia ya no era sinónimo de agitación y demagogia, sino el emblema de una nueva realidad social y psicológica, profundamente arraigada en la naturaleza humana. En efecto: "el imperio de la palabra democracia no es un accidente local

78 Guizot, De la democracia. Véase Aguilar Rivera, Ausentes del universo, pp. 276-314.

79 Guizot, De la democracia, p. 5.

80 Guizot, De la democracia, p. 6. 
y pasajero; es el desarrollo, otros dirían el desencadenamiento de toda la naturaleza humana, sobre toda la línea y en todas las profundidades de la sociedad". ${ }^{81}$ La democracia había avasallado al gobierno representativo, a la "soberanía de la razón" de los doctrinarios. ${ }^{82}$ Cuando la república había utilizado el apellido "democrático", se había consumado un triunfo: "titulándonos república democrática, no proclamamos la guerra, sino la victoria, la victoria de la democracia. La democracia ha vencido; queda sola en el campo de batalla; levanta su visera; se nombra y toma posesión de su conquista". El problema era que en el seno de la persuasión democrática había un déficit de gobernabilidad y una ingenua fe anárquica. En efecto: "las sociedades democráticas no tienen el privilegio de ser menos necesario en ellas el espíritu de gobierno, ni de ser diferentes o menos elevadas que en otra sociedad sus condiciones vitales". Washington sabía que en una sociedad democrática, como en cualquier otra, "no se gobierna desde abajo arriba". ${ }^{83}$ Luis $\mathrm{Na}$ poleón lo había entendido a cabalidad. Por ello había "restablecido en el seno de la Francia democrática el orden y el poder; ha creído y probado que se podía servir y gobernar a una sociedad democrática sin condescender con todas sus inclinaciones; y en eso está su grandeza". ${ }^{84}$

No es, pues, sorprendente que el terremoto de 1848 produjera en los años siguientes un profundo realineamiento ideológico en México. No sería, sin embargo, sino hasta después de la rebelión de Ayutla que la revolución de 1848 comenzó a tener ecos positivos y significativos. La agitación ideológica inició a

\footnotetext{
81 Guizot, De la democracia, p. 8.

82 Los liberales doctrinarios creían que la razón, no la voluntad popular, debía ser soberana. Sobre este grupo, véase Rosanvallon, Le moment Guizot; Diez DEL Corral, El liberalismo doctrinario.

83 Guizot, De la democracia, p. 15.

84 Guizot, De la democracia, p. 14.
} 
mediados de la década de $1850 .{ }^{85}$ La guerra con Estados Unidos también radicalizó el discurso ideológico. En esos años Europa fue retratada como políticamente atrasada. El rechazo a la soberanía popular y la pauperización de las masas eran el magma de un "volcán de ideas democráticas" que estaría en continua erupción en esa parte del mundo. ${ }^{86}$

Los nuevos usos de la palabra democracia pudieron constatarse en un discurso conmemorativo de la independencia nacional pronunciado por el joven abogado liberal Ignacio L. Vallarta el 16 de septiembre de $1855 .{ }^{87}$ El texto es un parteaguas en la historia de la democracia en México. La revolución francesa había sido para Vallarta "el más grande cataclismo social que haya presenciado la historia contemporánea para derrumbar hasta la última piedra de un ruinoso edificio político". ${ }^{88} \mathrm{La}$ revolución había cometido excesos, es cierto, pero éstos habían sido necesarios. México mismo se había sacudido el yugo de la dictadura de Santa Anna. El símbolo de la fe política de los revolucionarios de Ayutla era la democracia:

[...] institución sagrada que no es más que el evangelio de los gobiernos; la democracia, que es la exigencia de la civilización; la democracia, que es el porvenir político del mundo, es el símbolo de la fe que profesa la revolución de 855. Yo quiero, señores, la democracia en todo su desarrollo práctico, con toda su influencia política, con todo su alcance social; porque sólo la democracia, así entendida, sabrá dar solución a nuestro gran problema nacional, y

${ }^{85}$ Clara E. Lida, “The Democratic”, en Thompson, The European Revolutions, p. 71.

${ }^{86}$ SANDERs, The Vanguard, p. 92.

87 Vallarta, "Discurso que en el solemne aniversario del día 16 de septiembre de 1810, leyó en la plaza principal de Guadalajara, el C. Ignacio L. Vallarta, miembro de la sociedad literaria 'La Esperanza'”, en Vallarta, Archivo inédito, pp. 103-111. Vallarta tenía por aquel entonces 25 años.

88 Vallarta, "Discurso", p. 104. 
sabrá marcar el hasta aquí a nuestro inaudito desorden: yo quiero la democracia pura, sin mezcla de heterogéneos elementos, porque sólo ella es potente a contener nuestra ruina; yo quiero la democracia pura, sin ajenas combinaciones, porque amo a esa institución que hace al hombre hermano del hombre, que sólo reconoce el mérito personal, que sólo acata la virtud individual, que proclama la unidad de la gran familia humana, que realiza los mandatos del Hombre-Dios. ${ }^{89}$

La revolución democrática debía barrer con todos los males seculares de México: los fueros y privilegios, la desigualdad en la propiedad territorial, los monopolios y los impuestos indirectos que oprimían a los consumidores. Para que la revolución de Ayutla pudiese satisfacer las exigencias de la época debía abandonarse “sin reserva en manos de la democracia”. Esto era así porque ella

[...] predica la igualdad ante la ley y destruye fueros absurdos: porque la democracia acepta los principios de la escuela económica-liberal, y no se aviene con una división territorial injusta y desproporcionada, con la amortización de los capitales, con el monopolio, con los abusos de lo que podemos llamar contribución eclesiástica [...] la democracia, viniendo contra el origen de nuestros infortunios terminará, pues, la dolorosa crisis que sentimos, y librará al país de las desgracias que seriamente le amenazan. ${ }^{90}$

Aquí se observa claramente una peculiar operación ideológica: una fe en el poder regenerador de un ente producto de la reconciliación entre democracia y liberalismo. Vallarta se daba cabal cuenta de que la democracia podía ser un poderoso corrosivo:

${ }^{99}$ Vallarta, "Discurso", p. 107.

90 Vallarta, "Discurso", p. 107. 
[...] si se adopta la escuela democrática con todos sus principios y con todas sus consecuencias, si se proclama esa escuela como una institución política entre nosotros, el resultado inmediato va a ser, yo mismo lo diré, la destrucción de todo lo que existe, el aniquilamiento de nuestra organización social. Está bien: yo mismo convengo en todo; pero no queráis sacar de esos hechos necesarios una consecuencia falsa a todas luces: que la escuela democrática es destructora. ${ }^{91}$

La democracia sólo le daría el empujón final a una época caduca para precipitarla al abismo. En efecto, en épocas de crisis es preciso "que la ruina de todo lo viejo y que anda haciendo mal en la sociedad, sea un hecho consumado, para que las exigencias sentidas sean satisfechas por las instituciones nuevas [...] si es necesaria absolutamente la destrucción de todo lo existente, cúlpese a nuestra excepcional época, y no a la escuela democrática” ${ }^{92}$ La democracia no era sino la satisfacción de las “necesidades de nuestra época”. Por ello, la salvación de México no podía ser obra "sino de las ideas democráticas". ${ }^{93}$

Esta visión redentorista de la democracia rechazaba explícitamente la vía moderada, ensayada en los lustros anteriores, que proponía una democracia "mezclada” o equilibrada por elementos aristocráticos, como argüían Otero y Pizarro. La palabra connotaba ahora una panacea de regeneración nacional. Para servir esa función simbólica el término experimentó necesariamente una explosión semántica. El propio Vallarta se excusó de entrar en la discusión de los "principios constitutivos de la democracia”; su objetivo no era definir a la democracia sino blandirla como un arma contra los enemigos conservadores.

\footnotetext{
91 Ignacio L. Vallarta, “Discurso”, pp. 108-109.

92 Ignacio L. Vallarta, “Discurso”, p. 109.

93 Ignacio L. Vallarta, "Discurso”, p. 109.
} 
La democracia había sido vinculada así a un tipo de patriotismo liberal en un contexto de confrontación ideológica. La libertad se había fundido de manera inseparable con la democracia. De esta forma se forjaba un vínculo, y un relato, mítico. Al final de la Guerra de Tres Años, en 1861, Ignacio Manuel Altamirano se quejaba: "el martirologio de la democracia mexicana es bien largo". ${ }^{44}$ La historia prehispánica y colonial era una zaga de despotismo. Altamirano así lo reconocía: "Pero se me dirá: ¿Y la libertad? ¿Y la democracia? ¿De donde vinieron? ¿Acaso no llegaron incubadas estas ideas en las ideas religiosas de nuestros conquistadores?" 95 No, respondía Altamirano. La libertad era anterior al cristianismo. En lo que hace a la democracia, ésta no había sino "transmigrado". En efecto,

[...] muerta en Grecia, prostituida en Roma, ahogada en las repúblicas italianas de la Edad Media, parecía haberse extinguido para siempre, porque la reyedad llegó a enseñorearse del mundo cuando apareció de improviso, vergonzante, en Holanda y en Suiza, terrible, aunque fugaz en Inglaterra, tempestuosa y omnipotente en Francia, y joven, vigorosa e impaciente en el Nuevo Mundo. Y ése es el destino, ésa la tendencia de la civilización, ése es el porvenir de la humanidad: jla democracia!.96

El pueblo mexicano había nacido con la aspiración democrática. Y ese anhelo había sido frustrado durante cientos de años: el pueblo había sacrificado su dignidad soberana "por muchos siglos". Así, la lucha por la libertad se volvía indistinguible de la lucha por la democracia. De igual manera, México era parte de un proceso civilizatorio de emancipación:

94 Altamirano, "Discurso pronunciado en el Teatro Nacional de México la noche del 15 de septiembre de 1861 por el ciudadano Ignacio M. Altamirano”, en Aguilar Rivera, La espada, p. 406.

95 Ignacio M. Altamirano, "Discurso”, p. 408.

96 Ignacio M. Altamirano, "Discurso”, p. 408. 
[...] la Francia nos enseñó el camino en 93 y su ejemplo contagia al mundo ya: el pueblo hace temblar al papa en el Vaticano [...] pronto imperará en toda su plenitud la democracia evangélica [...] Sí, nosotros realizaremos el puro, el santo, el divino liberalismo religioso, tal cual lo concibiera el virtuoso Hijo del carpintero de Nazareth. ${ }^{97}$

El uso político de la democracia ahora involucraba no sólo la falsificación de la génesis histórica del gobierno representativo sino la entronización de una epopeya religiosa.

Ignacio Ramírez, por su parte, elaboraba esta teodicea democrática que buscaba reconciliar a la religión -que no a la Iglesia- con la democracia, la independencia y el liberalismo. Para Ramírez,

[...] el catolicismo romano, pagano en tiempo de los Césares, feudal en la Edad Media y monárquico en el día, en vano se pone la careta de la democracia para que no le conozca la tea revolucionaria: toda nuestra esperanza se fija en los innumerables y buenos creyentes que, fieles al estandarte del Crucificado, no quieren verlo arrancado de los templos para que sirva de picota a las puertas de los palacios; ellos lo proclaman símbolo de caridad y justicia, y no de ambición y de rencores; por eso es que ellos nos prometen que un día, la primera bendición del sacerdote será para

97 Ignacio M. Altamirano, "Discurso", p. 409. Esta asociación entre democracia y religión no era privativa de los mexicanos. Por ejemplo, en Colombia, desde la década de 1840, tanto liberales como conservadores hablaban en esos mismos términos. Los liberales afirmaban que "enseñar al pueblo sus deberes y derechos, moralizar sus costumbres e ilustrar sus creencias, todo con las santas doctrinas de la democracia y del Evangelio, son cosas, la verdad, harto importantes". Por su parte, los conservadores alegaban que la democracia, es decir, "la igualdad ante la ley política y civil", había sido "consecuencia natural de la igualdad fraternal del cristianismo". Citados por VANEGAS, "Colombia/Nueva Granada”, pp. 126-127. 
la democracia, y el primero de sus anatemas para la intolerancia y para el despotismo. ${ }^{98}$

\section{LA DEMOCRACIA HECHA CONSTITUCIÓN}

Perdido el significado canónico de gobierno tumultuario arcaico, ¿en qué se convirtió la democracia? La polisemia de la palabra puede constatarse cabalmente en los debates constituyentes. En los debates del congreso de 1856-1857 los diputados utilizaron el término con al menos once significados distintos. La democracia a veces era empleada como una bandera política, otras era sinónimo del moderno gobierno representativo. El significado anterior no desapareció del todo, y a veces la democracia connotaba el gobierno directo del pueblo de los antiguos. En ocasiones también significó el gobierno de las mayorías, una forma de dominio popular. En ciertos contextos fue sinónimo de igualdad. El contexto político forjó una asociación positiva en la cual la democracia se hallaba críticamente vinculada al federalismo. La democracia significó respeto a las minorías. Relacionado con este significado, el término también connotó respeto a la conciencia pública y libertad de culto. Frecuentemente la democracia fue solo un adjetivo positivo, una manifestación edificante de la naturaleza humana. De forma aspiracional, la democracia se utilizó para denotar un régimen político ideal o deseable. Finalmente, la democracia tuvo el sentido republicano de no dominación, es decir, de autogobierno no sujeto a terceros. $^{99}$

98 Ramírez, "Discurso cívico pronunciado el 16 de septiembre de 1861, en la Alameda de México, en memoria de la proclamación de la Independencia”, en Ramírez, Obras, t. 1, p. 140.

99 Zarco, Crónica del Congreso; Zarco, Historia del Congreso. El significado de la democracia como no dominación no es sorprendente, pues, como afirma David Brading, "aparte de sus ideales y proyectos liberales universales, los liberales no tenían más que un gran mensaje para su pueblo: la necesidad 
La palabra democracia, y otras asociadas, tuvieron una presencia ubicua en los debates del congreso constituyente. Los términos “democracia”, “democrático”, “antidemocrático” y “demócrata” fueron mencionados en 329 ocasiones. ¿En qué contexto se utilizaron? Fueron empleados en la discusión de diversos temas (58 en total). Sin embargo, cuatro concentran el mayor número de menciones: características de los diputados con 52 menciones (15.8\%), libertad de conciencia con 45 menciones (13.6\%), juicio por jurados con $17(5.1 \%)$ y supresión del senado con 15 menciones (4.5 por ciento).

A continuación se presentan varias tablas que sistematizan el uso de estos términos.

\section{Tabla 1}

CONGRESO CONSTITUYENTE DE 1856-1857

\begin{tabular}{rlc}
\hline & Tema & $\begin{array}{c}\text { Número de } \\
\text { menciones }\end{array}$ \\
\hline 1 & Sobre las características de los diputados & 52 \\
2 & Sobre la libertad de conciencia & 45 \\
3 & Sobre el juicio por jurados & 17 \\
4 & Sobre la supresión del Senado & 15 \\
5 & Sobre la incorporación de Coahuila a Nuevo León & 14 \\
6 & Sobre reformas futuras a la Constitución & 12 \\
7 & Presentación del proyecto de Constitución & 11 \\
8 & Sobre la elección del presidente & 10 \\
9 & Sobre las facultades del Congreso & 10 \\
10 & Sobre los dictámenes necesarios para aprobar una ley & 9 \\
11 & Sobre la elección directa & 9 \\
12 & Proyecto de Ley Orgánica Electoral & 9 \\
13 & Ley Orgánica de Libertad de Prensa & 7 \\
14 & Sobre el derecho de propiedad & 7 \\
15 & Supresión de los fueros & 7 \\
16 & Sobre el Distrito Federal & 6
\end{tabular}

absoluta de la independencia de todo gobierno extranjero". David A. Brading, "El patriotismo liberal y la Reforma mexicana", en Brading, Mito y profecía, p. 146. 
Tabla 1 (continúa)

CONGRESO CONSTITUYENTE DE 1856-1857

\begin{tabular}{|c|c|c|}
\hline & Tema & $\begin{array}{l}\text { Numero de } \\
\text { menciones }\end{array}$ \\
\hline 17 & Sobre el preámbulo de la Constitución & 5 \\
\hline 18 & Sobre la renuncia de Juan Álvarez & 5 \\
\hline 19 & Sobre las facultades del poder judicial & 5 \\
\hline 20 & Abolición de las alcabalas & 4 \\
\hline 21 & Proyecto de Constitución & 4 \\
\hline 22 & Sobre la libertad de enseñanza & 4 \\
\hline 23 & Apertura de las sesiones del Congreso & 4 \\
\hline 24 & Manifiesto que proclama la Constitución de 1857 & 3 \\
\hline 25 & Sobre el número de diputados & 3 \\
\hline 26 & Sobre la dictadura de Santa Anna & 3 \\
\hline 27 & Sobre la supresión del territorio de Tehuantepec & 3 \\
\hline 28 & Sobre la suspensión de garantías en caso de invasión & 3 \\
\hline 29 & Sobre la pena de muerte & 3 \\
\hline 30 & Comisión encargada de voto de gracias & 2 \\
\hline 31 & Instrucciones del gobernador de Jalisco & 2 \\
\hline 32 & $\begin{array}{l}\text { Sobre el establecimiento de que la soberanía nacional } \\
\text { reside en el pueblo }\end{array}$ & 2 \\
\hline 33 & Sobre el veto en el ejecutivo y el legislativo & 2 \\
\hline 34 & Sobre la desamortización de las fincas & 2 \\
\hline 35 & $\begin{array}{l}\text { Sobre la incompatibilidad del cargo de diputado con } \\
\text { cualquier otro }\end{array}$ & 2 \\
\hline 36 & Sobre los jesuitas & 2 \\
\hline 37 & Sobre los tribunales de circuito y de distrito & 2 \\
\hline 38 & Sobre la libertad de imprenta & 2 \\
\hline 39 & Comunicación al Congreso & 2 \\
\hline 40 & Reaparición del periódico El Siglo XIX & 2 \\
\hline 41 & $\begin{array}{l}\text { Convocatoria al Congreso Extraordinario } \\
\text { Constituyente }\end{array}$ & 1 \\
\hline 42 & Dictamen de la Comisión de Guerra & 1 \\
\hline 43 & Dictamen de la Comisión Especial & 1 \\
\hline 44 & Ley Orgánica de Guardia Nacional & 1 \\
\hline 45 & Proyecto sobre los artículos 70, 15 y 24 & 1 \\
\hline 46 & Sobre el artículo $3^{\circ}$ & 1 \\
\hline 47 & Sobre el cobro de peajes & 1 \\
\hline 48 & Sobre el libre comercio & 1 \\
\hline 49 & $\begin{array}{l}\text { Sobre el nombramiento de jefes políticos en los } \\
\text { territorios }\end{array}$ & 1 \\
\hline
\end{tabular}




\begin{tabular}{llc}
\hline & Tema & $\begin{array}{c}\text { Número de } \\
\text { menciones }\end{array}$ \\
\hline 50 & Sobre investir al ejecutivo de facultades extraordinarias & 1 \\
51 & Sobre la Constitución de 1824 & 1 \\
52 & $\begin{array}{l}\text { Sobre la facultad del presidente de conceder amnistías e } \\
\text { indultos }\end{array}$ & 1 \\
53 & Sobre la inmunidad de los funcionarios públicos & 1 \\
54 & Sobre la mujer & 1 \\
55 & Sobre las características de los jueces de la Suprema & 1 \\
& Corte & 1 \\
56 & $\begin{array}{l}\text { Sobre las propuestas del señor Arizcorreta } \\
57\end{array}$ & Sobre el decreto que crea una compañía de obreros para \\
& las fábricas de armas nacionales & 1 \\
58 & Sobre las características de los ciudadanos & 1 \\
& Total & 329 \\
\hline
\end{tabular}

Clasificación por temas de las menciones de los términos: "democracia”, "democrático", “antidemocrático” y “demócrata” en el Congreso Constituyente de 18561857. Elaboración propia a partir de: ZARCO, Crónica del Congreso Extraordinario Constituyente 1856-1857, $1^{\text {a }}$ y ZARCO, Historia del Congreso Extraordinario Constituyente 1856-1857, estudio preliminar.

Los requisitos que debían cumplir los representantes provocaron una animada discusión, pues las restricciones de residencia fueron denunciadas como antidemocráticas. Por ejemplo, el diputado Villalobos afirmó el 26 de septiembre de 1856:

[...] si conforme a los principios democráticos de igualdad todos los ciudadanos pueden ser diputados, ¿por qué no han de poder ser electos fuera del lugar de su residencia? En teoría no puede encontrar el menor apoyo esta exclusión. La Constitución más liberal que se ha dado la Francia proclamó que todo francés en ejercicio de sus derechos es elector y elegible para todos los cargos públicos. ${ }^{100}$

10026 de septiembre de 1856. Zarco, Crónica del Congreso, p. 881. 
Arriaga defendió el artículo sosteniendo que "no hay justicia en calificar de antidemocrática la restricción que sólo tiende a hacer justicia a las quejas de los pueblos contra la absorción y monopolio del poder que ejerce la capital”. ${ }^{101}$

Sorprendentemente la democracia fue mencionada de forma desproporcionada en un tema, la libertad de conciencia, que ahora consideraríamos como de derechos civiles. Por ejemplo, el 29 de julio de 1856, Ponciano Arriaga arguyó:

[...] será de todo punto imposible que la sociedad sea libre si no se le conceden estas garantías; que al tratarse de la organización externa se trata de su culto, de su manifestación externa y de su principio social; que es imposible proclamar democracia dejando una religión dominante; que el derecho que consulta el artículo es un derecho absoluto y propio de todos los hombres y todos los pueblos, y el cual no puede tener taxativa; que precisamente por evitar los abusos del clero, lo ha puesto la comisión en esos términos; que este artículo es el mismo que se halla en la Constitución de los EstadosUnidos, aunque redactado de otra manera; que la comisión lo que ha querido es que lleguemos a conquistar el verdadero principio de la democracia popular. ${ }^{102}$

El debate sobre los juicios por jurados también evocó el uso del término. Al respecto, Filomeno Mata adujo en defensa de los jurados:

El orador no ha querido decir que el pueblo puede ser arbitrario, sino que los que temen sus fallos tienen que renegar de la democracia, porque la democracia se funda en el principio de que el hombre es esencialmente bueno y justo; al establecer el jurado se quiere que el pueblo sea legislador y juez, y darle la sanción de la ley, es decir, la

101 Zarco, Crónica del Congreso, p. 883.

10229 de julio 1856. Zarco, Crónica del Congreso, p. 577. Cursivas mías. 
aplicación de la pena. Si de la ley más justa se puede abusar cuando la ley pasa por la razón del pueblo, cuando él la aplica conforme a su conciencia, los fallos serán justos, favorecerán a la inocencia y harán desaparecer los inconvenientes y defectos de la misma ley. ${ }^{103}$

Sobre la propuesta de suprimir el Senado, Francisco Zarco argumentó en contra:

[...] se ha llegado a decir que el senado es una institución aristocráti$\mathrm{ca}$, pero nadie puede creer que el que habla abrigue ni una sola idea de aristocracia. El senado puede ser republicano y democrático, si se deriva del pueblo, y, al plantear en México el sistema representativo, es menester considerar no sólo la República y la democracia, sino el sistema federal y la necesidad de equilibrar a las entidades políticas que constituyen la federación. ${ }^{104}$

En lo que hace a la tipología de usos de la democracia (tabla 2), el significado más recurrente (28\%) fue aquel que entendía a la democracia como "el gobierno de la mayoría o gobierno del pueblo”. De esta forma, Zarco proclamó el 4 de agosto de 1856: "Yo creo que el pueblo mexicano, que me honró encargándome que lo representara en esta asamblea, es ilustrado, tolerante y generoso y está preparado para la reforma que proclama la democracia”. ${ }^{105}$ De manera similar, Mata defendió la idea de democracia como gobierno de las mayorías cuando discutió el veto del ejecutivo y las condiciones para superarlo: "pero ya sean necesarios dos tercios, ya la simple mayoría para insistir en una ley, siempre habrá democracia, y ni en uno ni en otro caso se faltaría a los buenos principios”. ${ }^{106}$

10328 de julio 1856. Zarco, Crónica del Congreso, p. 541. Cursivas mías.

10410 de septiembre 1856. Zarco, Crónica del Congreso, p. 834. Cursivas mías.

105 Zarco, Crónica del Congreso, p. 678.

10615 de octubre de 1856. Zarco, Crónica del Congreso, p. 949. 
Tabla 2

CONGRESO CONSTITUYENTE DE 1856-1857

\begin{tabular}{llc}
\hline Tipología & Conteo \\
\hline 1 & $\begin{array}{l}\text { Democracia como bandera política } \\
2\end{array}$ & 13 \\
& $\begin{array}{l}\text { Democracia como gobierno representativo, no directo, } \\
\text { de los modernos }\end{array}$ & 26 \\
3 & $\begin{array}{l}\text { Democracia como gobierno directo del pueblo, de los } \\
\text { antiguos }\end{array}$ & 11 \\
4 & $\begin{array}{l}\text { Democracia como gobierno de la mayoría o gobierno } \\
\text { popular }\end{array}$ & 92 \\
5 & Democracia vinculada a la igualdad \\
6 & $\begin{array}{l}\text { Democracia vinculada al federalismo } \\
7\end{array}$ & 35 \\
8 & $\begin{array}{l}\text { Democracia como respeto a las minorías } \\
\text { libertad de cultos }\end{array}$ & 17 \\
9 & $\begin{array}{l}\text { Democracia como adjetivo, valor positivo o idea } \\
\text { positiva de la naturaleza humana }\end{array}$ & 21 \\
10 & $\begin{array}{l}\text { Democracia como descriptiva de un régimen político } \\
\text { ideal o deseable }\end{array}$ & 57 \\
11 & $\begin{array}{l}\text { Democracia como autogobierno no sujeto a terceros } \\
\text { Total }\end{array}$ & 64 \\
\hline
\end{tabular}

Clasificación de las menciones de los términos: "democracia", "democrático", “antidemocrático" y "demócrata”, según tipos, en el Congreso Constituyente de 1856-1857. Elaboración propia a partir de ZARCo, Crónica del Congreso Extraordinario Constituyente 1856-1857, $1^{\mathrm{a}}$ y ZARCO, Historia del Congreso Extraordinario Constituyente 1856-1857.

La segunda connotación más común de la "democracia” fue un valor positivo de la naturaleza humana. Por ejemplo, Ponciano Arriaga argüía que el verdadero derecho divino era "la ley de la democracia, la igualdad y la fraternidad". ${ }^{107}$ De igual manera, Ignacio Ramírez, al defender las potestades del congreso, adujo:

¿Por qué, pues, el Congreso constitucional ha de tener mayores trabas? ¿Por qué se ponen tantos embarazos a su acción? ¿Por qué

1077 de julio de1856. Zarco, Crónica del Congreso, p. 472. 
se quiere que discuta tantas veces y que, desconfiando de sí mismo, vaya a pedir limosna de luces al ministerio, que ha de ser más sabio y más patriota? Porque no se tiene fe en el progreso de la humanidad, porque no se tiene la conciencia de la democracia. ${ }^{108}$

El tercer significado más recurrido de la democracia fue: "Democracia como descriptiva de un régimen político ideal o deseable". Por ejemplo, el 16 de junio de 1856 Ponciano Arriaga declaró:

La democracia, ya lo hemos dicho en otra parte, es el mando, el poder, el gobierno, la autoridad, la ley, la judicatura del pueblo. El gobierno popular y democrático se funda en la igualdad de los hombres, se manifiesta por su libertad, se consuma y perfecciona por la fraternidad; por el precepto nuevo, por la fórmula social del cristianismo, los hombres son iguales, porque todos son libres, porque todos son hermanos. ${ }^{109}$

De la misma manera, el diputado Soto sostuvo respecto a la instrucción necesaria para mantener un régimen democrático:

El gobierno debe determinar los autores para la enseñanza, y esto me basta; los autores más a propósito, los más ilustres en la materia, los más conformes al desarrollo completo de la democracia. Por la elección que se haga de los autores de asignatura, se elevará la inteligencia del pueblo a la altura del siglo en que vivimos. ${ }^{110}$

La democracia entendida como igualdad apareció frecuentemente en los debates del constituyente. Por ejemplo, Vallarta adujo el 8 de agosto de 1856:

10822 noviembre 1856. ZArco, Crónica del Congreso, p. 1048.

10916 de junio 1856. Zarco, Crónica del Congreso, p. 319.

110 Manuel Fernando Soto, 11 de agosto 1856. Zarco, Crónica del Congreso, pp. 720-721. Cursivas mías. 
Yo, lo mismo que la comisión, reconozco que nuestra Constitución democrática será una mentira, más todavía, un sarcasmo, si los pobres no tienen sus derechos más que detallados en la Constitución. Yo, en fin, conozco como la comisión que entre nosotros no andan escasos esos improvisados señores feudales, que nada les falta para poder vivir bajo un Felipe II o bajo un Carlos IX.111

De la misma forma, el diputado Cendejas denunciaba la superioridad de la cámara alta: "El Senado no ha representado más que los intereses de ciertas clases sociales, reconocidas por el Gobierno colonial, y no podía representar otra cosa, puesto que desde 1824 la ley electoral relativa a la segunda cámara se separó siempre del principio democrático". ${ }^{112}$

Finalmente, la democracia a menudo no significó otra cosa que una bandera política en tiempos de guerra civil. Por ejemplo, Lafragua le comunicó al Congreso el 27 de marzo de 1856: "el gobierno, que está altamente satisfecho de la conducta del ejército y de la guardia nacional, felicita cordialmente al Congreso por el triunfo que han alcanzado los buenos principios y porque queda asegurada firmemente en la República la causa de la democracia”. ${ }^{113}$ Similarmente, sobre la renuncia de Juan Álvarez, una comisión del Congreso sostuvo: "no sería, pues, justo que la representación nacional, admitiendo la renuncia del protector de la democracia mexicana, consignara el principio de que la nación nada debe a sus buenos hijos y a sus más leales y distinguidos servidores". ${ }^{114}$

El contraste entre los dos congresos constituyentes de la primera mitad del siglo xix en lo que hace al uso de la palabra democracia es muy notable. En el de 1823-1824, como se dijo

111 Ignacio L. Vallarta, 8 de agosto 1856. Zarco, Crónica del Congreso, p. 707.

11210 de septiembre 1856. Zarco, Crónica del Congreso, p. 583.

113 Zarco, Crónica del Congreso, p. 74.

11427 mayo 1856. Zarco, Historia del Congreso, p. 227. 


\section{Tabla 3}

CONGRESO CONSTITUYENTE DE 1823-1824

\begin{tabular}{llc}
\hline & Tipología & Menciones \\
\hline 1 & $\begin{array}{l}\text { Democracia como bandera política } \\
2\end{array}$ & 0 \\
& $\begin{array}{l}\text { Democracia como gobierno representativo, no directo, } \\
\text { de los modernos }\end{array}$ & 3 \\
3 & $\begin{array}{l}\text { Democracia como gobierno directo del pueblo, de los } \\
\text { antiguos }\end{array}$ & 2 \\
4 & $\begin{array}{l}\text { Democracia como gobierno de las mayorías o gobierno } \\
\text { popular }\end{array}$ & 1 \\
5 & Democracia vinculada a la igualdad & 0 \\
6 & $\begin{array}{l}\text { Democracia vinculada al federalismo } \\
7\end{array}$ Democracia como respeto a las minorías \\
8 & $\begin{array}{l}\text { Democracia como respeto a la conciencia pública y la } \\
\text { libertad de cultos }\end{array}$ & 0 \\
9 & $\begin{array}{l}\text { Democracia como adjetivo, valor positivo o idea positiva } \\
\text { de la naturaleza humana }\end{array}$ & 0 \\
10 & $\begin{array}{l}\text { Democracia como descriptiva de un régimen político } \\
\text { ideal o deseable }\end{array}$ & 0 \\
11 & $\begin{array}{l}\text { Democracia como autogobierno no sujeto a terceros } \\
\text { Total: }\end{array}$ & 1 \\
\hline
\end{tabular}

Tipología de las menciones del término "democracia" en el Congreso Constituyente de 1823-1824. Elaboración propia a partir de Secretaría de Gobernación, Acta Constitutiva de la Federación: Crónicas 1823-1824, México, Secretaría de Gobernación, Cámara de Diputados, Cámara de Senadores, 1974; Secretaría de Gobernación, Constitución Federal de 1824: Crónicas, México, Secretaría de Gobernación, Cámara de Diputados, Cámara de Senadores, 1974; Instituto de Investigaciones Legislativas, Historia parlamentaria: sesiones secretas 1821-1824, México, Cámara de Diputados, 1984.

al comienzo, el término apareció muy pocas veces (8) -y con escasos significados-, como es posible observar en la tabla 3.

Como puede verse, el significado moderno de democracia, entendida como gobierno representativo, recibe casi el mismo número de menciones que el sentido clásico del término: gobierno directo del pueblo, de los antiguos. La democracia no se había naturalizado aún en el discurso. El cambio semántico y 
conceptual que tuvo lugar en los siguientes 35 años fue pasmoso. Como afirma Elisa Cárdenas,

[...] de modelo teórico de Gobierno, el concepto se torna en un complejo conglomerado de significados: gobierno del pueblo soberano y representado; libertad y principalmente liberalismo; voluntad popular y aun heroísmo; independencia y sobre todo: vocación enraizada en el pasado de un pueblo y exigencia del presente para el cumplimiento de un destino civilizador. ${ }^{115}$

Curiosamente, al volverse polisémica, la democracia perdió la singularidad política que había tenido, así fuera de manera negativa, en el pasado. Se diluyó de manera notable para comprender muchos otros sentidos no estrictamente políticos. El poder normativo detrás de la idea de gobierno del pueblo sufrió así una merma. Tal vez ello explique por qué, en medio de una victoria conceptual arrasadora, la democracia perdió en el congreso constituyente de 1856-1857 una de sus más importantes batallas políticas: la lucha por el voto directo. La democracia había ganado en la arena de la retórica cívica, pero no en el campo del autogobierno. ${ }^{116}$ En otros países, como Colombia, donde los conservadores no fueron derrotados, por muchos años los partidos se disputaron la palabra democracia. Ambos se presentaron como sus artífices y verdaderos defensores. ${ }^{117}$

115 Cárdenas Ayala, “La escurridiza”, p. 90.

116 El sufragio masculino universal había sido ya adoptado (propuesto por un moderado, como Otero) en el Acta de Reformas de la constitución de 1847. La batalla democrática siguiente, y que se perdió en el constituyente de 18561857, fue la del voto directo en las elecciones. No sería sino hasta 1911 que se abandonaron las elecciones indirectas.

117 Vanegas, “Colombia/Nueva Granada”, p. 127. 


\section{CONCLUSIÓN}

La trayectoria política del término democracia en México llevó a la fusión de esta idea con otras, principalmente el liberalismo y el federalismo. Esta fusión sería el producto simbólico de la victoria de los liberales en la guerra civil y la intervención extranjera. Habría que preguntarse si para la democracia ésta no fue una victoria pírrica. El desdibujamiento del término, mezclado con el civismo en la oratoria cívica, fue una consecuencia de su empleo como arma retórica. La democracia, entendida como panacea de regeneración, no podía sino desilusionar a sus fieles. Paradójicamente, para los creyentes en el proyecto radical de la democracia, su derrota se debió a la voluntad de la mayoría. Zarco capturó este sentir admirablemente. Pocos días después de haberse promulgado la constitución de 1857 sostuvo:

[...] nosotros creíamos que había llegado la hora de poner en práctica todos los principios de la democracia con todas sus consecuencias; nos equivocamos, hubo todavía transacciones, trabas, emplazamientos y medidas a medias; tenemos que inclinarnos respetuosamente ante la mayoría, aceptamos la nueva Constitución como fuente de la legalidad y como medio de que un día triunfen las ideas progresistas, porque de ellas es el porvenir. ${ }^{118}$

Desde el punto de vista teórico, la reflexión sobre la democracia fue más rigurosa, pero de menor consecuencia, en el breve interludio moderado de la década de 1840 en la cual Otero y Pizarro propusieron diversas formas de readmitir esta forma de gobierno en el seno del moderno gobierno representativo. Después de 1855 la democracia se convirtió en una poderosa bandera política de vagos contornos, pero capaz de movilizar

118 Francisco Zarco, "El orden constitucional”, El Siglo XIX (14 feb. 1857), en Aguilar Rivera, La espada, p. 347. 
ideológicamente a los liberales. La democracia fue así devorada por la retórica cívica y patriótica, reclutada para el esfuerzo simbólico de la guerra civil.

\section{REFERENCIAS}

AdAms, John, "A Defence of the Constitutions of Government of the United States of America”, en George W. Carey (ed.), The Political Writings of John Adams, Washington, Regnery, 2000.

Aguilar Rivera, José Antonio, Ausentes del universo. Reflexiones sobre el pensamiento politico hispanoamericano en la era de la construcción nacional, 1821-1850, México, Centro de Investigación y Docencia Económicas, Fondo de Cultura Económica, 2012.

Aguilar Rivera, José Antonio (comp.), La espada y la pluma. Libertad y liberalismo en México (1821-2005), México, Fondo de Cultura Económica, 2012.

Alamán, Lucas, Historia de México, t. V, México, Imprenta de Victoriano Agüeros, 1885.

Aristóteles, La Política.

Brading, David A., Mito y profecía en la historia de México, México, Vuelta, 1988.

Caetano Hargain, Gerardo, "Itinerarios conceptuales de la voz 'democracia’ en Iberoamérica (1770-1870)”, en FernandeZ Sebastián, 2009.

Cámara de Diputados, Crónicas del Acta Constitutiva de la Federación, México, Comisión Nacional para la Conmemoración del Sesquicentenario de la República Federal y el Centenario de la Restauración del Senado, 1974.

Cámara de Diputados, Crónicas: Constitución Federal de 1824, México, Comisión Nacional para la Conmemoración del Sesquicentenario de la República Federal y el Centenario de la Restauración del Senado, 1974.

Cárdenas Ayala, Elisa, “México/Nueva España”, en Fernández Sebastián, 2009, pp. 149-161. 
CÁrdenas Ayala, Elisa, "La escurridiza democracia mexicana”, en Alcores, 9 (2010), pp. 73-91.

Cotlar, Seth, "Languages of Democracy in America from the Revolution to the Election of 1800", en InNes y PHIL, 2013, pp. 15-21.

Covo, Jacqueline, Las ideas de la Reforma en México (1855-1857), México, Universidad Nacional Autónoma de México, 1983.

Craiutu, Aurelian, A Virtue for Courageous Minds: Moderation in French Political Thought 1748-1830, Princeton, Princeton University Press, 2016.

Cuevas, Luis G., Porvenir de México, México, Imprenta de Ignacio Cumplido, 1851, 2 volúmenes.

Diez del Corral, Luis, El liberalismo doctrinario, Madrid Centro de Estudios Constitucionales, 1984.

Dym, Jordana, “Centroamérica”, en Fernández Sebastían (dir.), vol. 1, 2009.

Fernández Sebastián, José (dir.), Gerardo Caetano Hargain (coord.), Diccionario político y social del mundo iberoamericano. La era de las revoluciones, 1750-1850, vol. 1, Madrid, Fundación Carolina, Sociedad Estatal de Conmemoraciones Culturales, Centro de Estudios Políticos y Constitucionales, 2009.

Fontana, Biancamaria, The Invention of the Modern Republic, Cambridge, Cambridge University Press, 1994.

Guizot, François, De la démocratie en France, París, Gallimard, 1847.

Guizot, François, De la democracia en Francia, México, Tipografía de R. Rafael, 1849.

Illades, Carlos y Adriana Sandoval, "Nicolás Pizarro: literatura y utopía en el siglo XIX”, en Iberoamericana, 22 (1998), pp. 26-40.

InNes, Joannna y Mark Philp (eds.), Re-imagining Democracy in the Age of Revolutions. America, France, Britain, Ireland 1750-1850, Oxford, Oxford University Press, 2013.

Manin, Bernard, Los principios del gobierno representativo, Madrid, Alianza, 1998. 
Maquiavelo, Nicolás, Discursos.

Montesquieu, Carlos de, El espiritu de las leyes.

OTERo, Mariano, Ensayo sobre el verdadero estado de la cuestión social y politica que se agita en la República Mexicana, México, Ignacio Cumplido, 1842.

Palti, Elías (comp.), La política del disenso, México, Fondo de Cultura Económica, 1998.

Pizarro, Nicolás, La libertad en el orden. Ensayo sobre derecho público en que se resuelven algunas de las más vitales cuestiones que se agitan en México desde su independencia, México, Imprenta de Andrés Boix, 1855.

Ramírez, Ignacio, Obras, México, Editora Nacional, 1952.

Rosanvallon, Pierre, La consagración del ciudadano, México, Instituto Mora, 1999.

Rosanvallon, Pierre, Le moment Guizot, París, Gallimard, 1985.

Sanders, James E., The Vanguard of the Atlantic World. Creating Modernity, Nation, and Democracy in Nineteenth-Century Latin America, Durham, Duke University Press, 2014.

Sinkin, Richard. The Mexican Reform. A Study in Nation-Building, Austin, University of Texas Press, 1979.

Smith, Adam I., "The Fortunate Banner: Languages of Democracy in the United States, c. 1848”, en InNes y Philp, 2013.

Thompson, Guy (ed.), The European Revolutions of 1848 and the Americas, Londres, Institute of Latin American Studies, 2002.

Tocqueville, Alexis de, El Antiguo Régimen y la Revolución, México, Fondo de Cultura Económica, 1967.

Tocqueville, Alexis de, La democracia en América, México, Fondo de Cultura Económica, 1957.

Vallarta, Ignacio L. (comp. Manuel González Oropeza), Archivo inédito: Vallarta hombre y funcionario, México, Suprema Corte de Justicia de la Nación, 1993. 
Vanegas, Isidro, “Colombia/Nueva Granada”, en Fernández Sebastián, 2009.

WiLEntz, Sean, The Rise of American Democracy, Nueva York, Norton, 2005.

Zarco, Francisco, Crónica del Congreso Extraordinario Constituyente 18561857, México, Secretaría de Gobernación, 1979.

Zarco, Francisco, Historia del Congreso Extraordinario Constituyente 18561857, estudio preliminar de A. Martínez Báez, México, El Colegio de México, 1956. 